\title{
Article
}

\section{Anarchism and Health}

Scott, Niall William richard

Available at http://clok.uclan.ac.uk/22158/

Scott, Niall William richard ORCID: 0000-0001-5120-4132 (2018) Anarchism and Health. Cambridge Quarterly of Healthcare Ethics, 27 (02). pp. 217-227. ISSN 0963-1801

It is advisable to refer to the publisher's version if you intend to cite from the work. http://dx.doi.org/10.1017/S0963180117000561

For more information about UCLan's research in this area go to http://www.uclan.ac.uk/researchgroups/ and search for < name of research Group>.

For information about Research generally at UCLan please go to http://www.uclan.ac.uk/research/

All outputs in CLoK are protected by Intellectual Property Rights law, including Copyright law. Copyright, IPR and Moral Rights for the works on this site are retained by the individual authors and/or other copyright owners. Terms and conditions for use of this material are defined in the policies page.

\section{CLoK}

Central Lancashire online Knowledge www.clok.uclan.ac.uk

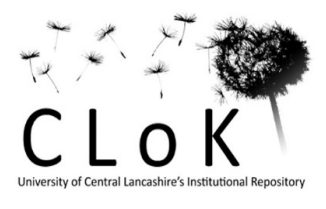




\section{Special Section: Justice, Healthcare, and Wellness}

2

\section{Anarchism and Health \\ NIALL SCOTT}

Abstract: This article looks at what anarchism has to offer in debates concerning health and healthcare. I present the case that anarchism's interest in supporting the poor, sick, and marginalized, and rejection of state and corporate power, places it in a good position to offer creative ways to address health problems. I maintain that anarchistic values of autonomy, responsibility, solidarity, and community are central to this endeavor. Rather than presenting a case that follows one particular anarchist theory, my main goal is to raise issues and initiate debate in this underresearched field in mainstream bioethics.

Keywords: anarchism; health; autonomy; responsibility; solidarity; state power; corporate power

\section{Introduction}

The ways in which anarchist thought can creatively contribute, even provide solutions, in current debates about health is a subject that has gained little attention in bioethics. In anarchist circles, health forms an important part of the very general challenges that activists and agitators present to mainstream modern, local, and global society. Articulations around climate, energy usage, diet, disease, lifestyle, impact of workplace behavior, and the environment are part of the political expression of many anarchist challenges to the world today, but are rarely placed under the banner of health. These concerns for anarchism are, to a large degree, not just challenges to power, hierarchy, institutions, and structures; they also are very much about health. From the outset, it can be seen that anarchism's relationship to health is a vast subject, and a short piece such as this will not do it justice. My main aim here is to raise issues, set the scenes, and, I hope, initiate debate about the possibilities and opportunities available for research in the area of anarchism and health. I will be more concerned with setting up a framework for discussion than with a particular argument regarding one or another form of anarchism in relation to health. I use the term "anarchism" broadly, and recognize that the matters presented here will elicit different responses and treatments depending on which anarchistic theory is held. In doing so, I propose that any anarchist approach to health focuses on the values of autonomy, responsibility, community, and solidarity. I do not enter into a detailed discussion of the philosophical implications of maintaining these values, but simply present them as a starting point for further debate.

\section{Defining Anarchism}

Anarchism is a political movement and perspective that is opposed to the hierarchical power of government and other coercive institutions. It has a long and diverse history, and anarchist practices had been identified long before the term itself had currency. Pierre Joseph Proudhon, can be seen as the first "self-styled

I thank Anne-Marie Stephani for her assistance in editing and proofreading this article. 


\section{Niall Scott}

anarchist," 1 well known for his phrases such as "all property is theft" and "anarchy is order." In the late 1860 s, anarchism more properly grew into a social and political movement. Prince Peter Kropotkin provided the first full explanatory definition of anarchism in the Encyclopaedia Britannica ${ }^{2}$, holding that it was "the name given to a principle or theory of life and conduct under which society is conceived without government." 3 Anarchism is a diverse movement that advocates freedom and individualism on the one hand, and communitarian collectivism on the other; however, all forms favor addressing solutions from the bottom up rather than imposing them from the top down.

It may well be the case that the popular and clichéd image of the anarchist is not one who is immediately concerned with health, but this is far from the truth, as Richard Cleminson ${ }^{4}$ points out in his work on Spanish anarchism. In practice also, this clichéd image is clearly false, and one only needs to look at the activist and anarchist interest in health on websites ${ }^{5}$ to see that many anarchist concerns are intimately bound up with health issues, be they public, social, global, or individual health concerns. They frequently come under other headings - climate change, ecology, and renewable energy use to name but a few-and there are countless pressure groups and activist networks on a global level conscientiously supporting the search for equity justice and autonomy in healthy living. For example, the debate surrounding fracking as a source for carbon-based energy can be framed in terms of a fundamental concern regarding human and environmental health. ${ }^{6}$ To be more accurate then, there is documentation of the interest that anarchism has in health, but it is found in online forums and in pamphlets, and can be witnessed at protests. Even at the very beginnings of anarchist thought, the Russian anarchist activist Mikael Bakunin identified health as a major concern, including opposition to using health a means of making monetary profit. It also expresses that healthcare can be achieved in a communal context:

First of course are medical services, which will be free of charge to all inhabitants of the commune. The doctors will not be like capitalists, trying to extract the greatest profit from their unfortunate patients. They will be employed by the commune and expected to treat all who need their services. But medical treatment is only the curative side of the science of health care; it is not enough to treat the sick, it is also necessary to prevent disease. That is the true function of hygiene. ${ }^{7}$

My contention is that an anarchistic approach to health can reclaim health as a common good. We have an opportunity and responsibility to provide creative ways of thinking about promoting health that undercuts the state and private stranglehold on this public need. Neither the state nor the private sector are necessarily capable of providing the most efficient distribution of health needs and resources. The motives of both are suspect, based on combinations of self-perpetuation and profit. The poor, the sick, and the unhealthy are often the most excluded people in society, and are further marginalized by corporate and state goals. The inclusive and communitarian nature of anarchism seeks to address such issues head on, but with bottom-up rather than top-down solutions. However, there is very little critical engagement in the possibilities provided by creative and anarchistic thinking in bioethics literature. 


\section{Anarchism and Health}

\section{Autonomy and Responsibility}

What kinds of values does anarchism have to offer the debate? I will first discuss some values that are identified in health ethics elsewhere. For a considerable length of time, the field of bioethics in ethics education and as a result healthcare professionals' education has been strongly influenced (but not exclusively so) by the American approach of principalism. Tom Beauchamp and James Childress's theory is built around a set of principles: autonomy, beneficence, non-maleficence (do no harm), and justice. ${ }^{8}$ These provide not only a theoretical foundation for approaching moral problems as they may be encountered in practice, but also a philosophical outlook that seeks to direct one to solutions based on balancing these principles, as there may be situations in which they come into conflict. This approach, however, is subject to criticism and debate, ${ }^{9}$ and one can often find alternative values discussed. For example, the move to develop a more European approach presented and argued for in the literature, expresses solidarity, precaution, and dignity. Matti Häyry has suggested that the promotion of a set of European values ought to be about the opening up discussion rather than about the imposition of a set of values or the suppression of one set of values by another. ${ }^{10}$ The Nuffield Council's Report on Ethics and Public Health ${ }^{11}$ identifies some principles under the banner of a liberal model of stewardship. It identifies autonomy, avoiding harm and community as value terms underpinning the pursuit of health. However, it gives an important role to the state in promoting public health, assuming that the term "stewardship" is sufficient to ward off coercive influences and paternalism, and that health policy ought to be compatible with the views of the public. From an anarchist viewpoint, any mention the role of the state will always sound a warning bell. It will instead be concerned with questions such as: How does the public acquire the education and the information to act in a way that promotes health as a good that is not bound up with the problematic influences of medical discourse and state, corporate, and institutional power? Considering the potential that anarchism has in its activist contribution to health and its strong interest in recognizing health as a battleground where power and state control can be challenged, anarchists are in a position take an active part in this critical exploration of the kinds of values that matter in the pursuit of health in general.

It is clear that one of the main concepts promoted thus far is autonomy, and a second that we can identify is responsibility. The anarchist promotion of autonomy is particularly well suited to supporting challenges to health concerns, because it recognizes health as worth pursuing for its own sake and not subject to instrumental thinking in any form. Even more importantly, it would see health as a prerequisite for autonomy. Where one's health is compromised, so is one's ability to be fully autonomous. Arguably, autonomy and health exist in a biconditional relationship with each other. Where autonomy is defined only as the capacity for rational self-determination, it can be quite restricting in that it requires the imposition of a judgement that an individual is competent to make certain kinds of choices. As A.J. Davis puts it, in the realm of healthcare, competency is often in the eye of the beholder. ${ }^{12}$ It matters then, to conceive of an understanding of autonomy that does not immediately invoke the capacity to impose judgement, but rather is truly self-determining and supports an individual in pursuit of that person's life projects and health as a good. An open approach to autonomy allows for debate, disagreement, and difference. Anne J. Davis usefully reminds us that 


\section{Niall Scott}

autonomy is a moral good, but should not be a moral obsession. ${ }^{13}$ Such a good in conjunction with health by necessity cannot be convincingly attained in solitude, rather it is a good that can only be pursued in community.

Understanding autonomy encounters a problem: The tension between it and community. This is a problem that has occurred in anarchist thought and movement right back to its early years. Enrico Malatesta, in an essay on individualist and communist/associationist anarchism, saw no strong difference between the solidaire goals of associationist anarchism and the freedom goals of individualist anarchism except, rather humorously, for the suggestion that justice and equity and freedom could not be achieved through individualist anarchism. ${ }^{14}$ Murray Bookchin refers to the tension between individualist anarchism and communist anarchism as unresolved, juxtaposing lifestyle anarchism with social anarchism. ${ }^{15}$ It is a debate, however, that is also not unfamiliar in healthcare ethics, where this difference expresses itself through discussions concerning communitarian and individualist approaches to healthcare. These, in part, articulate questions on the extent to which the state can legitimately legislate for individual health and lifestyle choices or questions on the conflict between autonomy and beneficence, where altruism might require one to act in the interest of the other and limit one's individual goals. However, these conflicts frequently occur when values are instrumentalized, or where one value is subordinated as a principle in pursuit of another. This is clear in public health debates, ${ }^{16}$ for example, the contestation regarding the smoking ban implementation and its effects on individual health and on communities, from the family, the workplace, and the pub/café culture; or, as shall be expanded on, the issue of fluoridation of drinking water.

\section{Solidarity and Community}

In addition to autonomy and responsibility, debates and criticisms in anarchist circles concerning the current state of affairs of health concerns focus on promoting the values of community and solidarity. These are often supported through organizing and coming together in health collectives and protest and pressure groups. The value of solidarity can be a powerful concept to employ with regard to health and the pursuit of a common good. Willam Rehg defines solidarity as "a quality of human association, specifically the cohesive social bond that holds a group of people together in an association they both understand themselves to be part of and value." 17 Rehg, however, denies that there can be solidarity that involves irreducibly social goods. Of course in an open definition such as this, solidarity can apply to a wide range of values, even objectionable ones, which groups can hold in common. Solidarity with regard to health needs other cooperating values to give it substantial normative force. This force can be achieved where health is treated as an irreducible social and common good. It is something that we all hold in common. The normative weight required to support solidarity can be provided by articulating the values of autonomy, community, and responsibility with the goal of health in mind.

Where anarchist argument can succeed, is in working in areas that already compliment some of the goals mentioned. Anarchist thought, especially anarchosyndicalist or communist anarchist thought, can find much in common with communitarian approaches to health. For example, Michael Parker has argued that regarding mental health, we need a healthy relationship between communities 


\section{Anarchism and Health}

2

and service users, in the shape of finding the best relationships between the needs of individuals and those of the community as a whole. ${ }^{18}$ In mental health, considerations of balancing community safety and health need to be able to complement the needs and promote the autonomy of those with mental health difficulties. He attacks autonomy in the libertarian principalist approach to medical and healthcare ethics of Beauchamp and Childress, ${ }^{19}$ as this, together with justice, non-maleficence, and beneficence reduces decisionmaking to the sphere of the detached reflective individual. It does not take into account the opportunities and contexts of communities in which such concerns take place. Michael Parker holds that, against the proliferation of calls for individual rights, these principalist values of autonomy, justice, non-maleficence and beneficence cannot come without corresponding responsibilities, and that solutions to moral problems cannot be conceived of in terms of anything other than social relationships and the pursuit of ways of life that involve participation with others. ${ }^{20}$ The communitarian case, like the anarchist case, recognizes that health problems are shared problems. However, I think that anarchist thought can add to communitarian ideas in its experience and interest in specifically supporting those poor, sick, and unhealthy who are marginalized and excluded from communities. Sadly, the sick, poor, and unhealthy are often treated through exclusion, rather than inclusion; we might as well think of the sick as being treated as if they have been criminalized for their conditions. The way in which the needy and sick, and the normal and abnormal are classified and are excluded has us participating in a kind of global open prison. Anarchism, in its opposition to power and hierarchy, has the opportunity to ensure that the community ought never to become a new rallying point for a special kind of integrity that needs to be preserved at all costs regarding the "problem" of the unhealthy and the sick. Anarchism in its promotion of perpetual revolution is and ought to be always humble to the dissolution of power structures, in order to maximize inclusivity, yet maintain a sense of the local, in communities. Anarchism, as a movement for social change, has the opportunity to bring resolution to the relationship between autonomy and community, as health is an irreducible good, a common good, and common need that cannot be subject to instrumentalization or compromise.

\section{A Problematic Past, but a Promising Future}

As mentioned, anarchist thought has always been tied in with an interest in human health, both individual and public. However, its history does have a darker side. As Cleminson informs us, the Spanish anarchist movement in the 1860s was actively concerned about health, but its primary interest was in the question of "improving the quality of life of the populace," 21 and closely tied to eugenic thinking at the time. Even though Robert Allerton Parker, who coined the term "Birth Control" advocated women's sexual freedom in a sarcastic harsh attack on middle class American feminism, ${ }^{22}$ many of these early anarchistic ideas and challenges were intimately bound up with eugenic ideas. Margaret Sanger, who also published letters in Emma Goldman's Mother Earth, ${ }^{23}$ on the one hand championed women's freedom, but on other hand was a supporter of eugenics. In her essay A Plan for Peace she advocated that there should be an application of: "a stern and rigid policy of sterilisation and segregation to that grade of population whose progeny is tainted or whose inheritance is such that objectionable traits may be transmitted to offspring." 24 


\section{Niall Scott}

In the same publication her concern was directed to women's health, linking it firmly to the pursuit of peace:

The third step would be to give special attention to the mother's health, to see that women who are suffering from tuberculosis, heart or kidney disease, toxic goitre, gonorrhoea, or any disease where the condition of pregnancy disturbs their health are placed under public health nurses to instruct them in practical, scientific methods of contraception to safeguard their lives-thus reducing maternal mortality. The above steps may seem to place emphasis on a health programme instead of on tariffs, moratoriums and debts, but I believe that national health is the first essential factor in any programme of peace. ${ }^{25}$

However, Peter Kropotkin spoke out strongly in Goldman's publications against the sterilization of the unfit, calling for more to be done in investigating and studying the social roots and causes of the diseases that were the targets of those eager to promote sterilization as a solution. In defense of the poor, workers, and the marginalized, he asks who is to be counted as unfit in the pursuit of making socialism work? These are the very people who could not only be building socialism, but could also benefit more from healthy environmental conditions: "And then once these questions as to who are the unfit have been raised, don't you think that the question as to who are the unfit must necessarily come to the front? Who indeed? The workers or the idlers? The women of the people, who suckle their children themselves, or the ladies who are unfit for maternity because they cannot perform all the duties of a mother? Those who produce degenerates in the slums or those who produce degenerates in the palaces?"26

There is a history in Britain worth recognizing on the subject of self-organization, autonomy, and health, in which anarchistic creative thinking initiated ideas that were eventually taken up in the early development of the National Health Service (NHS). The Peckham Health Centre, founded in 1935, was run on principles that could be classed as anarchistic: "For many of us the experience of Peckham was a unique laboratory of anarchy, it was a study of the living structure of society, exploring principles of organisation applicable not only to health but to every aspect of social welfare, to housing and above all to the organisation of work." 27

Unfortunately, it was the advent of the postwar NHS that saw its demise. David Goodway recounts the movement as being one that aimed at five conditions: health overhauls, consultation, consisting of family (only) and local membership, financial contributions by members to the center, and the building and maintaining of autonomy. It was its commitment to these that led to the downfall of the experiment, as its focus on administrative autonomy and contributory rather than free and open access, and on the cultivation of health rather than treatment, did not sit well with the direction that the postwar welfare state was developing.

Nonetheless, the ideas concerning health collectives and a shared approach to health, in which individuals could be experts concerning their own bodies, were being rediscovered, and these "discoveries" continue today. People marginalized (through lack of access and/or poverty for example) and not being heard in the public and private health systems, can benefit from the expertise of others, including professional medical specialists, rather than merely submitting to the authorities of the clinic as the center of expertise. One of many good examples of such 


\section{Anarchism and Health}

engagement in a society that is heavily compromised in the extreme with regard to the corporate stranglehold limiting access to healthcare comes from the Ithaca Health Alliance fund in the United States, which describes itself as a "locally controlled not for profit health security." 28 It provides health support for those who cannot find needed medical attention because of the unaffordability of health services in the United States for the un- and underinsured. By pooling resources and material and medical expertise, and addressing the patient's ability to pay or not to pay, this collective undermines the stranglehold of the private insurance sector on people's lives. Financial affordability is made possible by opening up the space for people to exchange services required through bartering, offering time, community service, home visit credits, as well as hard currency. The emphasis is on local provision, and a free clinic exists as a result of the success of the health fund. Through supporting educational initiatives, such as the Ithaca Health and Wellness Fair, an emphasis is placed on reducing cost by the promotion of healthy lifestyle choices. Here is an example of anarchist principles in action: autonomy and collective community-directed thinking, working in solidarity and harmony. Further examples of autonomous health movements for the new thinking regarding health around the world can be found in a 2005 issue of Development, under the heading "Window on the World," where a series of health movements are listed, many of which promote autonomy, collective engagement, and women's' health concerns. ${ }^{29}$

\section{Corporate Problems, State Problems}

Anarchist thinking promoting collectivist approaches directly counters the role of the state in healthcare. This is a role that has been heavily corrupted by private incentives and the use of health as a mechanism to ensure the perpetuation of state power; it is difficult to see even what existing components of the welfare system can be rescued. Arguably, from the anarchist perspective, the nation-state-organized private partnership investment in health is one of the ways that the state manages to maintain order. It is a rather powerful mix: the political married to the capitalist system with the supposed aim of supporting a human need. The corporate invasion and privatization agenda of health often makes headline news in the United Kingdom. ${ }^{30}$ The combined targets of the state, industry, and institutions that support statist and corporate ideologies in health would appear to be insurmountable. The Nuffield Council's Report on Ethics and Public Health, published 10 years ago, 31 is replete with observations and suggestions that involve the role of the state and the individual in the pursuit of health. It presents a range of ethical positions and key examples (infectious diseases, alcohol and tobacco, obesity, and fluoridation) as areas where the state, community, individuals and industry play roles in public health promotion. The report claims to move more in favor of the responsibility of the community than the freedom of the individual, but advocates the role of the state as a steward of health. Under this model, the Nuffield Council report insists that the state has a responsibility to provide the conditions under which people can live healthy lives. The scope covered by this document is a good indication of the areas where anarchist thinking can respond, both negatively and positively. According to Goodway, the state and corporate health perpetuates poverty and illness, destroys mutual aid, and serves to bring about dependency and servility. ${ }^{32}$ Anarchism maintains that neither the state nor the private sector are necessarily capable of providing the most efficient distribution of health needs and resources. 


\section{Niall Scott}

1 This is because the motives of both are suspect, based on the combination of selfperpetuation and profit. Therapies rather than cures allow the maintenance of the market success of pharmaceutical industry, and, in addition, most pharmaceutical research is directed toward the lifestyle demands of affluent societies. The United Kingdom's Department for International Development in its research funding framework recognizes (albeit in a footnote with reference to Médicins Sans Frontìeres) that 46 times more money was spent on research into Viagra than into malaria. ${ }^{33}$ Furthermore, under the medical models of health and disease, "Everyday life occurrences are turned into medical problems, mild symptoms are portrayed as serious and risks become diseases" 34

State and corporate involvement in healthcare can invoke the imposition of ideas on the public that restrict genuine autonomy and the capacity to make health decisions on the basis of open access to information. Tash Gordon and Becs Griffiths hold more generally that through promoting medical and health fears and risks, these develop into self-obsessions, often disguising the political sources of health problems. Individualizing health on both the medical and political fronts makes consumers the source of health problems and also gives them sole responsibility for taking action on health. However, paradoxically for many, there is little autonomy in health decisionmaking; the state and/or private sector provide the route to good health. An anarchist approach can open the door to more autonomy in health, but in the context of community and solidarity. Offenses to autonomy even occur when government initiatives are masqueraded as health initiatives; for example, the fluoridation of the water supply as an attempt to combat caries comes across as an attempt at mass medication without considering consent from the public. The British Fluoridation Society promotes John Harris's argument in favor of fluoridation as "the professional philosopher's view." Harris treats the issue of fluoridation as centering on a conflict between the principles of autonomy and beneficence. He treats beneficence as the principle that promotes acting in the interests of others, and autonomy as individuals having permission to control their own lives and destinies in compatibility with others having similar control over their lives. ${ }^{35}$ These are contentious definitions of autonomy and beneficence, however, and their coming into conflict depends heavily on both being instrumentally conceived; that is, as a means to some other end, in this case the end being support of fluoridation, assuming that it does no harm to those who consume it. Correctly speaking, autonomy is not a principle on its own, but exercising respect for autonomy is. The capacity to act beneficently further is dependent on an agent acting autonomously; therefore, there are conceptual problems that require deeper analysis. Worse still, no alternatives are presented to fluoridation by Harris in his argument. Similarly, although the Nuffield Council's Report On Ethics and Public Health gives a more thorough treatment with regard to the benefits and risks of fluoridation, these focus on fluoridation rather than on the value of promoting better education and dietary change, and the alleviation of poverty in areas where dental caries is most prevalent. Bewilderingly, under the heading of "alternative treatments," alternative fluoride treatments are discussed! ${ }^{36}$ It can be seen, then, that information that allows genuine autonomous choice is absent where it is much needed, in areas where one might be drawn to inquire and search for information regarding fluoridation.

The anarchist challenge in promoting healthy living tackles individualist consumerism head on, but it offers a conceptual tension, not just in health, but in 


\section{Anarchism and Health}

1 political thinking also, as it looks to community and collective efforts that ought 2 also to leave room for autonomy. A difficult target is being confronted here: the combination of consumer health combined with government power. Health in our current context has ceased to be a common good and has become a public good mixed with a powerful economic component. That is to say, health is treated as a public good in that access to healthcare in terms of medical need involves the redistribution of funds acquired through taxation and or insurance. Ideally, a public good once produced ought to not incur any additional costs to the user, ${ }^{37}$ but this is no longer the case with healthcare; taxation does not cover the cost of health provision, and the private sector is now to a large degree involved through insurance and pharmaceutical industries, and public-private partnership in the provision of healthcare.

A positive example of change brought about in healthcare that complements anarchist thinking is seen in patient-centered healthcare. This promotes autonomy, responsibility, and community, such that "patient participating in determining appropriate management plans as their condition and motivation allow." 38 Terms such as "choice empowerment" and "participation" come to the fore in the relationship between patient and clinician/carer. The patient is brought back into focus, and attention is given to the input of caregivers, giving both a deserved voice. ${ }^{39}$ Alison Zucca et al. equate "ask the patient what they would like" with achieving quality of care. ${ }^{40}$ The main critical and practical effort in patientcentered care is found in the fields of mental health and in elderly and geriatric care. For example, in the field of dementia, patient-centered care has undergone a shift from the patient merely being an expression of signs and symptoms, to the person being treated. Research into the use of multisensory environments documents caregivers' positive experiences of patients with sensory deprivation who respond well to stimulus demands.. Furthermore, in this research, it has not only become clear that attentiveness to the patient's voice generates more humane care, but that the caregiver, starts to avoid the dehumanizing effects of institutionalization by thinking more creatively about patient need. Patient-centered care improves socialization and personal interaction and personal care, and reduces the use of punishment and the manifestation of verbal and physical abuse..$^{41}$ What might be accomplished if such thinking goes further? 4 Listening to the patient's voice, and an approach that can treat patients as 5 experts on their own bodies, in dialogue with practitioners, promote equality between the patient and practitioner by dismantling unhelpful hierarchies of knowledge, and preferring a dialogue.

\section{Concluding Remarks}

1 In this short article, I have sketched out some areas where the possibilities of anar42 chist approaches to health can inject interesting challenges to current problems in 43 health, and where creative solutions might be found that counter corporate and state 44 control. One of these is an emphasis on inclusion rather than exclusion of the sick 45 and unhealthy; another is to introduce ideas regarding health based on autonomy, 46 responsibility, solidarity, and community. Anarchist thought can also articulate 47 the difficult path between individual interest and social interests. I maintain that 48 anarchism has much to offer mainstream debates in bioethics and health, and 49 there is much scope here for further research. 


\section{Niall Scott}

\section{Notes}

1. Marshall P. Demanding the Impossible: A History of Anarchism, London: Harper Perennial Press; 2008:234

2. Kropotkin P. Anarchism. In: Encyclopaedia Britannica 1910; available at: https:/ /www.marxists.org/ reference/archive/kropotkin-peter/1910/britannica.htm (last accessed 28 July 2017).

3. See note 2, Kropotkin 1910.

4. Cleminson R. Anarchists for health: Spanish anarchism and health reform in the 1930s. Part I: Anarchism, neo-malthusianism, eugenics and concepts of health. Health Care Analysis, 1995;3(1):61-7.

5. See, for example, Hill M. Fragments of an Anarchist Public Health: Developing Visions of a Healthy Society, n.d.; available at http://anarchiststudies.mayfirst.org/node/301 (last accessed 26 July 2017). A vision of anarchist health care: mutual aid through self-managed health cooperatives. Anarchy and Health, November 3, 2011; available at https://backalleyradio.wordpress.com/2011/11/03/ a-vision-of-anarchist-health-care-mutual-aid-through-self-managed-health-cooperatives / (last accessed 26 July 2017).

6. Kovats S, Dpledge M, Haines A, Fleming LE, Wilkinson P. The health implications of fracking. The Lancet 2014;383(9919): 757-8.

7. Bakunin M. Bakunin on Anarchy, New York: Random House; 1971, at 371.

8. Beauchamp T, Childress JF. The Principles of Biomedical Ethics. Oxford: Oxford University Press; 2005.

9. See for example, Herissone-Kelly P. The principlist approach to bioethics and its stormy journey overseas. In: Häyry M, Takala T, eds. Scratching the Surface of Bioethics. Amsterdam/New York: Rodopi; 2003:65-77. Also see Herisonne-Kelly P. Determining the common morality's norms in the sixth edition of Principles of Biomedical Ethics. Journal of Medical Ethics 2011;37:584-7.

10. Häyry M. (2003) European values in bioethics, what why where and how to be used? Theoretical Medicine and Bioethics. 2003;24(3):199-214.

11. The Nuffield Council on Bioethics. The Nuffield Council Report, Public Health: Ethical Issues. Cambridge: Cambridge Publishers Ltd; 2007.

12. Davis AJ. Are there limits to caring? The conflict between autonomy and beneficence. In Leininger MM, ed. Ethical and Moral Dimensions of Care. Detroit: Wayne State University Press; 1990:27-28.

13. See note 12, Davis 1990, at 28.

14. Malatesta E. Individualism and communism in anarchism In: Richards V, ed. The Anarchist Revolution: Polemical Articles 1924-1931. London: The Freedom Press; 1995:18-22.

15. Bookchin M. Social Anarchism or Lifestyle Anarchism? An Unbridgeable Chasm. Chico, CA: AK Press; 1995.

16. Blacksher E. Public health. Ethics in Medicine. University of Washington School of Medicine; 2014; available at https:/ / depts.washington.edu/bioethx/topics/public.html (last accessed 29 July 2017).

17. Rehg W. Solidarity and the common good. Journal of Social Philosophy 2007;38(1):7-21.

18. Parker M. Individualism. In: Chadwick R, Levitt M, eds. Ethical Issues in Healthcare. London: Arnold Press; 1998:16-33.

19. See note 8, Beauchamp, Childress 2005.

20. See note 18, Parker 1998.

21. Cleminson R. Anarchists for health: Spanish anarchism and health reform in the 1930s. Part I: Anarchism, neo-malthusianism, eugenics and concepts of health. Health Care Analysis 1995;3(1):61-7.

22. Parker RA. Feminism in America. In: Glassgold P, ed. Anarchy! An Anthology of Emma Goldman's Mother Earth. Washington DC: Counterpoint; 2001 (originally published 1915):124-5.

23. Mother Earth! was a publication of the anarchist movement, edited by Emma Goldman and Alexander Berkmann. Its first issue appeared in 1906, and it continued until 1918. Shortly after, Goldman and Berkman were deported to Russia. It was a magazine dedicated to writings on the full spectrum of anarchist thought. An anthology of the magazine appeared in print in: Glassgold 2001.

24. Sanger M. A plan for peace. Birth Control Review 1932(April):107-8.

25. See note 24, Sanger 1932, at 107.

26. Kropotkin, P. The sterilisation of the unfit. In: Glassgold 2001, at 120-3.

27. Goodway D. Anarchism and the welfare state: The Peckham Health Centre. History and Policy 2007; available at http://www.historyandpolicy.org/policy-papers/papers/anarchism-and-the-welfarestate-the-peckham-health-centre (last accessed 20 October 2017). 


\section{Anarchism and Health}

1 28. http:/ /www.ithicahealth.org (last accessed 27 July 2017).

29. Humble M. Window on the world. Development 2005;48(4):144-50.

30. See, for example, new articles in the mainstream media in the United Kingdom on the privatization creep in healthcare: Jeremy Hunt is criticised for his role in $£ 650 \mathrm{~m}$ Virgin hospital deal, The Guardian, September 8, 2012; available at https:/ /www.theguardian.com/politics/2012/sep/09/ jeremy-hunt-virgin-hospital-deal; Doctor's searing chronicle of NHS piles pressure on Hunt, July 1, 2017; available at https://www.theguardian.com/society/2017/jul/01/junior-doctor-rachel-clarkenhs-lament-jeremy-hunt (last accessed 27 July 2017).

31. See note 11, Lord Krebs et al. 2007.

32. See note 27, Goodway 2007.

33. DFID, Research Funding Framework, 2005-2007; available at http:/ / webarchive.nationalarchives. gov.uk/20060403085825/http:/ /www.dfid.gov.uk/research/newresearch.asp, at 4 (last accessed 20 October 2017).

34. Gordon T, Griffiths B. Why society is making us sick. In: Do It Yourself, A Handbook for Changing our World. London: Pluto Press; 2007:78-107.

35. Harris J. The Ethics Of Fluoridation, 1989; available at http://www.bfsweb.org/facts/ethics/ ethicsharris.htm (last accessed 27 July 2017).

5 36. See note 11, Nuffield Council on Bioethics 2007, at 126-7.

16 37. Holcombe R. A theory of the theory of public goods. Review of Austrian Economics 1997;10(1):1-22.

38. Ersser SJ, Atkins S. Clinical reasoning and patient-centred care. In: Higgs J, Jones M, eds. Clinical Reasoning in the Health Professions. Amsterdam: Elsevier; 2000:67-77

39. Hope KW, Easby R, Waterman H. Finding the person the disease has - the case for multi sensory environments. The Journal of Psychiatric and Mental Health Nursing 2004;11:554-61.

0 40. Zucca A, Sanson-Fischer R, Waller A, Carey M, Broadie D. The first step in ensuring patient centred quality of care: Ask the patient. European Journal of Cancer Care 2017;26(4):1-13.

41. Hutchinson R, Hagar L. The development and evaluation of a Snoezelen leisure resource for people with a severe multiple disability. In: Hutchinson R, Kewin J, eds. Sensation and Disability: Sensory Environments for Leisure, Snoezelen, Education and Therapy, J. Chesterfield: Rompa; 1994:18-48. 


\section{AUTHOR QUERIES}

\begin{tabular}{|l|l|}
\hline QA & $\begin{array}{l}\text { The distinction between surnames can be ambiguous, therefore to ensure } \\
\text { accurate tagging for indexing purposes online (eg for PubMed entries), } \\
\text { please check that the highlighted surnames have been correctly identified, } \\
\text { that all names are in the correct order and spelt correctly. }\end{array}$ \\
\hline AQ1 & What does "it" refer to here? \\
\hline AQ2 & Please provide first name for A. J. Davis. \\
\hline AQ3 & Willam or William? \\
\hline
\end{tabular}

